\title{
Metacognition to Increase the Results of The Study in A Spreadsheet Lesson for Student Accounting
}

\author{
Widiyanto $^{1}$, Arief Yulianto ${ }^{2}$ \\ \{wied@mail.unnes.ac.id\} \\ 1,2Universitas Negeri Semarang, Indonesia
}

\begin{abstract}
Metacognisi can help learners to improve their learning, i.e. by encouraging learners to change the behavior of their learning. This research aims to find and test the effectiveness of the model metacognisi, therefore, then this model could be categorized as innovation in learning for inspiring teachers in implementing the metacognisi as being the paradigm of curriculum in 2013. The research question, are: 1) Whether metacognisi can improve performance (Learning Outcomes) learners in learning the spreadsheet?; the Learning Model 2) is Metacognisi with the help of Excell can further improve performance (Learning Outcomes) learners in learning the spreadsheet?. The research method used is the Class Action Research (ACR), with a sample of semester 2nd Student majoring in Accounting at Universitas Negeri Semarang by as much as 41 students. The learning cycle using twice cycles then found a modification of metacognisi with the help of the program Excel as a tool facilitating the understanding of the material. Then this model is tested with True Experimental with Pre - test Controll Group Design. A summary of this research is Metacognisi Learning can improve the performance of learners in learning the spreadsheet and Metacognisi learning with the help of Excell is very effective in improving learning outcomes.
\end{abstract}

Keywords: Metacognisi; Excell, Performance (Learning Outcomes), Student.

\section{Introduction}

Government Regulation number 19 year 2017 about changes to the Government Regulation number 74 year 2008 about teachers, on article 1 paragraph 1 States that the teacher is a professional educator with the main task of educating, teaching, guiding, directing, coaching, assessing and evaluating students in early childhood education path of formal education, elementary education, and secondary education. The role of teachers must be increasingly sharpened by developing competence, creativity, and innovation.

Hammond (2001, p. 10) says, knowledge is a construction of learning experiences, the development of knowledge which has been owned and the management of learning activities learners, more according to him explain at the time of the renaissance, learning is a process of thinking as an attempt to understand an idea and utilize the knowledge to the larger goal (Hammond, 2001, p. 2-5). While according to the tabula rasa theory advanced by John Locke (1632-1704) States that knowledge is a complex idea as a result of experience gained before. About the idea when knowledge is experience is also expressed by Kant (1724-1804) renewed the theory of Plato.

During this learning was implemented starting from ELEMENTARY SCHOOL to College still hasn't given a real experience to learners, therefore then the pemberlajaran metacognisi 
will give you the experience to learners. Metacognisi is the process of self-reflection learners in learning (Wenden, 1987, p. 573-592), further Metacognisi is a self-regulatory process of learners in learning. Therefore, the learning of metacognisi gives the learners to be able to judge for themselves whether they have adequate knowledge about the task that the proper strategy was accepted and untkuk completed a task in the study. The self assessment will help in the selection of strategies for completing the tasks in the study. If sustainability is a process of learning, then the process of absorption of knowledge should be judged and measured by implementing or applying the knowledge that has been understood. This is in accordance with the opinion of Sveiby (2001, p. 345) holds learning is measurable activities where learners can measure/monitor the knowledge acquired in the learning activities.

To measure of achievement by self learners, according to Schraw (1998, p. 113-116). they can measure its accomplishments in learning when learners can or cannot accomplish the task given teacher.

Metacognisi also are learning to cope with the routine, this is because according to Sani (2019:42), most of the students was only able to resolve the problem that is routine or ever worked on in school and not being able to work on the question of which measures the ability of a high level of thinking associated with the problems of everyday life.

This research aims to test the learning model metacognisi, in addition to developing learning models metacognisi in order for the model to be effective for learning achievement, learners in the study developed a model metacognisi with excell program assisted to accomplish the task.

Therefore the problems formulated are: (1) whether metacognisi can improve performance (Learning Outcomes) learners in learning the spreadsheet?; 2) Metacognisi Learning Model with the help of Excell can further improve performance (Learning Outcomes) learners in learning the spreadsheet?.

\section{Review Library.}

Research on Metacognisi by Syafmen (2013) describes the process of critical thinking students type steadiness style in solving the math problems. The type of research used in this research is descriptive research. The subject in this study was the high school student who has the steadiness of personality style on the even semester academic year 2011/2012, by observing the process of critical thinking in the observe of each step resolution according to Polya. With the results of the study showed that students can style steadiness solve math problems given critically. Similarly with Setyadi research (2018), also supports the opinion of metacognisi in mathematical problem solving for students. Research of Fajriani and Nurdahniar (2016) examined the results of student learning in mathematics lessons using metacognisi and the result declared there is increased.

The third research above with the subject of mathematical learning, while for the material outside of mathematics is still not a lot, this is because Metacognition is considered a way of thinking that is more mathematical approach or for science.

The research that will be presented are metacognisi to study accounting in making spreadsheets.

Wenden, (1987, p. 573-592) metacognisi is a process of self-reflection learners in learning. Brown et al., (1980, pp. 1-4). Metacognisi is the self regulation of the activities of the students and the strategies used, whereas Louca, (2008, p. 3) metacognisi is self knowledge, self awareness and self management of learners, three opinion as mentioned above can be inferred 
if metacognisi is stratergi learning with a learner self-reflection process with realizing the ability of self and how to manage yourself.

The material of the lectures on the spreadsheet is an application program that is used to manipulate data and present information in the form of rows and columns. It is part of the application program in Microsoft Excel, Excel has a tab menu 9, namely, Home, Insert, Page Layout, Formulas, Data, Review, View, Add-Ins and Acrobat. The Home tab contains iconsicon that is used to format numbers and text in rows, columns or cells. The Insert used to include a wide variety of objects such as a picture, clip art, shapes, smart art, charts, text boxes, headers footers, word art, object and symbol. Page Layout contains icon-icon used for printing such as margins, orientation, size, print area, and scale to fit. Formulas tab contains icon-icon functions used for data processing. Data tab contains icon-icon that is used to retrieve data from other sources such as Microsoft Access, SQL server or any other querybased application. Tab view contains icons to manipulate the display of the worksheet as normal page layout, or page break preview. The study of Accounting is learning that uses columns and columns. With the Application of learning will be easier. Pembanfaatan of excel can also be adjusted with the formula - formulas used in the calculations on a counting process on Financial Accounting.

On top of the already expressed metacognisi if suitable subjects or material science and mathematical nature, in terms of the calculation of accounting can be synchronised with the mathematical learning, therefore this research then use method Metacognition and excel applications because it has characteristics that are appropriate.

Metacognisi divided into self-knowledge (metacognitive knowledge) (Cantrell, 2010, p. 259) and self-management (metacognitive regulation) (Ertmer, 1996, p. 1-7; Lai, 2011, p. 7-9; Cantrell, 2010, p. 258-259). The selection of strategies is an activity control of learners (ParisWinograd, 1990, p. 1-11, Schraw, 2006, p. 113-123; Cantrell, 2010, p. 257-270) or learning management conducted learners (ParisWinograd, 1990, p. 12-15; Schraw, 2006, p. 113-123; Cantrell, 2010, p. 258-259) and experience the process of thinking learners (Flavell, 1979, p. 906909; Cantrell, 2010, p. 259).

\section{Research Approach}

This research will be conducted in UNNES with students studying spreadsheets for Accounting Majors 2 class as much as 76 students. Design research is the Research Action class that is expected to help teachers find a most appropriate strategies to improve the performance of learners in learning (Hole Mc Entee, 1999). Class action research is the research conducted by the teachers to find solutions to practical problems in the classroom (Korrey, 1993, p. 1).

The research of class action sebagaiman rendered in the following diagram: 


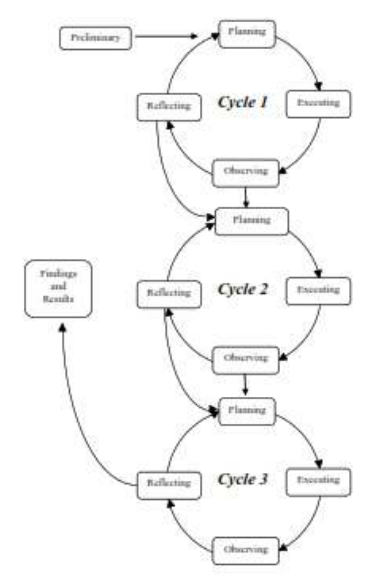

Preliminary, this stage is the stage of observing the activity of learning activities and the development of learners: Planning, stage make planning by implementing learning 3 cycles; Executing, that is, the stage of implementation of the study; Observing activities, researchers observe, ask yourself, collect information, Menalar and communicate; The reflecting, that is the end of learning, learners will be presenting about the things they have learned, the problems they face and their strategy to resolve the problems encountered; and final Findings and Results, after conducting a study in cycles 1,2 and 3 and the resulting document examines learners such as journal learning and selfesteem journal, researchers will make a conclusion.

Methods of Data collection and analysis of results, each activity of this learning will be recorded and all the documents used in the learning activities will be documented to find problems occurred, the solution is done and the development learning to learners. Each of these learning activities will be recorded and all the documents used in the learning activities will be didikumentasikan to find problems occurred, the solution that was done and the development of the learning learners. Using data sets that also through instruments will be analyzed using regression analysis and also with the $t$ test to see the effectiveness of the model applied.

\section{Conclusion}

Conclusions and suggestions of a theoretical framework of the Summary are:

1. The application of Metacognition to learning accounting learning with material spreadsheet can be implemented because had the suitability between metode and characteristics of material

2. Research using Research grade 3 action cycle which will identify the problems and obtain feedback for the development of the model.

3. If research is carried out in a procedural basis and obedient then this method will be able to improve student success in learning

\section{Refferences}

Brown, A. L. (1980). Theoritical Issues in Reading Comprehension: Perspective from Cognitive Psychology, Linguistics, Artificial Intelligence and Education. Metacognitive Development and Reading. New Jeersey: Lawrence Erlbaum Associates 
Cantrell, S. C., Almasi, J. F., Carter, J. C., Rintamaa, M. \& Madden, A. (2010). The Impact of a Strategy-Based Intervention on The Comprehension and Strategy Use of Struggling Adolescent Readers. Journal of Educational Psychology, Vol. 102, No. 2, pp. 257280

Ertmer, P. A. \& Newby, T. J. (1996). The Expert Learner: Strategic, SelfRegulated and Reflective. Instructional Science 24: I-24.

Fajriani dan Nurdahniar (2016); PENGARUH METAKOGNISI TERHADAP HASIL BELAJAR MATEMATIKA SISWA KELAS X SMA NEGERI SE KABUPATEN BULUKUMBA; Prosiding Seminar Nasional Volume 02, Nomor 1 ISSN 2443-1109; https://journal.uncp.ac.id/index.php/proceding/article/view/423/364

Flavell, J. H. (1979). Metacognition and Cognitive Monitoring. A New Era of CognitiveDevelopmental Inquiry. American Psychologist, Vol. 34, No. 10, pp. 906-911.

Hammond, L-D., Austin, K., Orcutt S. \& Rosso, J. (2001). How People Learn: Introduction to Learning Theories. Standford University School of Education

Lai, R. (2011). Metacognition: A Literature Review. Research Report. Pearson

Louca, E. P. (2008). Metacognition and Theory of Mind. Newcastle: Cambridge Scholar Publishing, pp. 1-2

Paris, S. G., \& Winograd, P. W. (1990). How metacognition can promote academic learning and instruction. In Lai, E. R. (2011). Metacognition: Literature Review. Research Report. Pearson.

Sani. R.A. (2019). Pembelajaran Berbasis HOTS (Higher Order Thinking Skills). Tangerang: Tira Smart

Schraw, G. (1998). Promoting Metacognitive Awareness. Instructional Science 26, pp. 113-125.

Schraw, G., Crippen, K. J., \& Hartley, K. (2006). Promoting self-regulation in science education: Metacognition as part of a broader perspective on learning. In Lai, E. R. (2011). Metacognition: Literature Review. Research Report. Pearson.

Setyadi, Danang (2018); Proses Metakognisi Mahasiswa Dalam Memecahkan Masalah Matematika (Studi Kasus Pada Mahasiswa Pendidikan Matematika UKSW); Kreano 9 (1) (2018): 93-99; file:///C:/Users/Pawiro/Downloads/13505-35979-1-PB\%20(1).pdf

Sveby, Karl-Eric. (2001). A Knowledge-Based Theory of The Firm to Guide in Strategy Formulation. Journal of Intellectual Capital, Vol. 2 No. 4, p.344358.

Wardi Syafmen (2013)" Profil Berfikir Kritis Siswa Kepribadian Steadiness Style dalam Memecahkan Masalah Matematika "Vol 3 No 02 (2013): Edumatica: Jurnal Pendidikan Matematika ; https://online-journal.unja.ac.id/index.php/edumatica/article/view/1580

Wenden, A. L. (1987). Metacognition an expanded view on the cognitive abilities of L2 learners. Language Learning 37 573-596 